Annals of Tropical Research 30[2]:1-21(2008)

(c) VSU, Leyte, Philippines

\title{
Development of bacterial blight resistant Mestizo hybrid maintainer and restorer lines through marker-aided backcrossing
}

\author{
Lucia M. Borines'1, Emilie O. Espejo', Robelyn T. Piamonte', \\ Casiana M. Vera Cruz ${ }^{2}$ and Edilberto Redoña ${ }^{2}$ \\ ${ }^{I}$ Dept. of Pest Management, VSU, Visca, Baybay, Leyte Philippines and \\ ${ }^{2}$ International Rice Research Institute, DAPO BOX 7777, Metro Manila Philippines
}

\begin{abstract}
This study was conducted to: 1) evaluate the reaction of Mestizo hybrids, their maintainer and restorer lines to Philippine Xanthomonas oryzae pv. oryzae races, 2) incorporate bacterial blight resistance genes to these lines via marker-aided backcrossing and 3) confirm the presence of introgressed $\mathrm{Xa}$ genes in the progeny of each backcross generation through phenotyping and molecular marker analysis.

Mestizo hybrids, their maintainer and restorer lines, IRBB62 donor, and checks were inoculated with ten Xoo races (12 isolates). Marker-aided backcrossing from IRBB62 donor (with $\mathrm{Xa4} / 7 / 21$ ) to each line was done to introgress target genes. The resistance genes in the advanced lines were confirmed using diagnostic Xoo races and analyses of linked DNA markers.

Mestizo 1,2 and 3, their maintainer and restorer lines (IR68888B, IR68897B, IR34686R, IR62161R, IR60819R) except IR58025B were similar to IRBB4 indicating the presence of $X a 4$ resistance gene in these lines. All the lines however, did not contain the $\mathrm{Xa} 7$ and $\mathrm{Xa} 21$ genes. Resistance genes $\mathrm{Xa} 7$ and $\mathrm{Xa21}$ were incorporated in addition to $\mathrm{Xa} 4$ to $\mathrm{BC}_{5} \mathrm{~F}_{2}$ progeny $\left(\mathrm{BC}_{5} \mathrm{~F}_{3}\right.$ seeds) of IR34686-179-1-2-1R, IR60819-34-2R, IR62161184-3-1-3-2R and IR6888B. Resistance genes were also incorporated to $\mathrm{BC}_{4} \mathrm{~F}_{1}$ progeny $\left(\mathrm{BC}_{4} \mathrm{~F}_{2}\right.$ seeds) of IR58025B and IR68897B. The presence of the genes was confirmed through linked markers.

The lines containing gene pyramids had increased resistance to bacterial blight and a wider resistance spectrum to Xoo races. Advanced backcross progeny were phenotypically similar to their recurrent $\mathrm{B}$ and $\mathrm{R}$ lines.
\end{abstract}

Keywords: rice, hybrid, maintainers, restorers, resistance

Correspondence: L. M. Borines Address: Dept. of Pest Management, VSU, Visca, Baybay, Leyte, Philippines. E-mail: lucyborines@yahoo.com; lucyborines@gmail.com. Tel. No. (053) 3352626

DOI: $10.32945 /$ atr3021.2008 


\section{INTRODUCTION}

To meet the increasing population's food requirements, rice production in the Philippines needs to be increased by $40-50 \%$ over current levels even with fewer inputs such as land, labor, water and pesticides (De Leon, 2003). A major strategy that can be used to meet this enormous challenge is to increase the yield per unit area per unit time that can be achieved through the use of the phenomenon of hybrid vigor or heterosis in F1 hybrids of rice.

The government launched the Ginintuang Masaganang Ani (GMA) Rice Program to help ensure food security and attain rice self sufficiency in the Philippines (Sebastian, 2003). One of the major strategies to achieve these goals is through hybrid rice cultivation. Recognizing the potential of hybrid rice to increase local rice production by at least $15 \%$ over the best inbred lines (Redoña et al. 2001; Virmani, 2001) and the prospects the technology offers in terms of increasing profitability of rice farming, the government has launched a comprehensive Hybrid Rice Program (HRP) in 1998 under the Department of Agriculture (Redoña, et al., 2001; De Leon et al. 2003).

One of the problems and constraints of the HRP in the country is the susceptibility of some hybrid parental and hybrids to bacterial blight (BB) caused by Xanthomonas oryzae pv. oryzae (Xoo) (De Leon et al. 2003). Borines (2001) reported the general susceptibility of five maintainer lines (IR58025B, IR62829B, LIANB, 913B and BOB) to ten Philippine Xoo races. Some of these lines were introduced to the country via collaboration mainly with Chinese institutions (Xu et al. 1995). In hybrid seed production, the practice of flag leaf clipping to facilitate out crossing further predisposes hybrid rice parental materials to blight infection. Improving the resistance of the components of hybrid rice production to bacterial blight is therefore necessary.

No chemical control measure is presently available for controlling this

disease. The use of resistant varieties is the only option available for minimizing the losses caused by BB. Fortunately, over 20 major genes for resistance to bacterial blight have been identified from rice and wild relatives (Kinoshita, 1995). Majority of these genes had been transferred to IR24 background in the form of near-isogenic lines (NILs, Ogawa et. al., 1990; 1991). These NILs had served as resistance gene donors to many elite rice lines. Some of these genes had been tagged with molecular markers which were used by rice breeders for the selection of the target genes (Ronald et. al., 1992, Blair and 
Mc Couch, 1997; Huang et. al., 1997; Yoshimura et. al., 1995; Sanchez et. al., 2000; Borines, 2001, Porter et al. 2003).

Chen et. al. (2000) introgressed Xa21 gene to an elite Chinese Restorer line "Minghui 63" via marker-aided backcrossing. Chen et al. (2001) improved the bacterial blight resistance of '6078', an elite restorer line of hybrid rice, by molecular marker-assisted selection. On the other hand, Borines (2001) had introgressed a pyramid of two to three and single resistance genes $(\mathrm{Xa} 4, \mathrm{Xa} 7$ and $\mathrm{Xa21}$ ) on five maintainer lines for hybrid rice production.

Among the public hybrids released and commonly grown in the country are the Mestizo's. The original Mestizo or PSBRc72H, which was released in 1997 represents the cross IR68284H and the pedigree IR58025A/1R34686179-1-2-1R. Mestizo 2 or NSICRc114H which was released in 2002 represents the cross IR75207H and the pedigree IR6888A/IR62161-1843-1-3-2R. Mestizo 3 or NSICRc116H was also approved for release in 2002 and represents the cross IR752127H and the pedigree IR60819-34$2 \mathrm{R}$. Based on field observations, the three hybrids have intermediate reaction to bacterial blight. (De Leon, 2003).

A proper evaluation of the reaction of the Mestizo hybrids, as well as their parental lines to the different Xoo races is necessary before they should be used for hybrid rice production. Improvement of the resistance of the Mestizo hybrids through incorporation of effective $\mathrm{BB}$ resistance genes is also necessary before they should be extensively deployed in the country for the hybrids to achieve the anticipated yield benefits. Before the hybrids can be improved though, their parents such as the maintainer lines and restorer lines must first be improved.

This study was conducted to: evaluate the reaction of Mestizo hybrids, their maintainer (B) and restorer (R) lines to Philippine Xanthomonas oryzae pv. oryzae Xoo races, incorporate bacterial blight resistance genes, Xa4, $\mathrm{Xa} 7$ and $\mathrm{Xa} 21$ from IRBB62 donor to the B and R lines via marker-aided backcrossing, and confirm the presence of introgressed $X a$ genes in the progeny of each backcross generation through phenotyping with diagnostic Xoo races and molecular marker analyses. 


\section{MATERIALS AND METHODS}

Procurement of Xoo isolates, rice near isogenic lines (NIL's), Mestizo hybrids and parental lines

Twelve Xoo isolates representing 10 races and BB NIL's were obtained from the International Rice Research institute (IRRI). The BB NIL's included IR24 (the susceptible check), IRBB4 (which contains $X a 4$ gene), IRBB7 (which contains $X a 7$ gene) IRBB 21(which contains $X a 21$ gene) and one pyramid line, IRBB62 (which contains three genes, $X a 4 / 7 / 21$ ). IRBB62 was used as the donor for $\mathrm{Xa} 4, \mathrm{Xa} 7$ and $\mathrm{Xa21}$ in the different crosses. The maintainer (B) lines (IR58025B, IR68888B and IR68897B) and Restorer (R) lines (IR34686R, IR60819R and IR62161R) of Mestizo hybrids, as well as the hybrids were procured from PhilRice.

\section{Phenotyping Mestizo hybrids and parentals}

The reaction of the three Mestizo hybrids, their B lines (IR58025B, IR68888B and IR68897B), R lines (IR34686R, IR62161R, and IR60819R), resistant donor IRBB62, IR24, IRBB4 (check for Xa4), IRBB7 (check for $X a 7$ ) and IRBB21 (check for Xa21) to ten Xoo races (12 isolates) was evaluated. This was done to confirm the earlier field observations on the intermediate reaction of the Mestizo hybrids to $\mathrm{BB}$, to evaluate the reaction of their $\mathrm{B}$ and $\mathrm{R}$ lines, and to possibly identify what resistance genes could be present in any of these lines. Phenotyping was also done to confirm the reaction of the IRBB62 donor, and to confirm the reaction of the susceptible and resistant checks. Parental phenotyping was conducted at the IRRI Greenhouse.

The ten Xoo races (12 isolates) used included: race1-PXO61, race2PXO86, race3a-PXO79, race3b-PXO340, race4-PXO71, race5-PXO112, race6-PXO99, race7-PXO145, race8-PXO280, race9a-PXO339, race9bPXO349 and race10-PXO341.

Rice seeds were pre-germinated in Petri plates lined with wet tissue paper. Two weeks later, these were transplanted to polyethylene pots filled with sterile soil and kept in irrigated trays inside the Department of Pest Management screenhouse. 
Inoculation was done when the plants were about 40 days old using the leaf-clipping method by Kauffman et. al. (1973). Two-day old culture of the isolates at a concentration of $10^{8} \mathrm{cfu} / \mathrm{ml}$ was used for inoculation. Disease scoring was done by measuring the length of BB lesions at 14 days after inoculation. The reaction of the lines was determined using the rating scale used by Carillo et al. 2003.

\section{Parental genotyping}

Parental genotyping was done at the Plant Breeding and Biotechnology Division (PBBD) of the Philippine Rice Research Institute (PhilRice). Fresh leaf samples preserved in ice in a bucket was transported to PhilRice Nueva Ecija where parental DNA extraction and analysis was done.

\section{DNA extraction and marker analysis.}

A mini-scale DNA extraction protocol used at the Genetics Laboratory at IRRI and also by Madamba, (2000) was used. The maintainer and restorer lines of three Mestizo hybrids were subjected to analysis of markers linked to target BB resistance genes. The characteristics of the markers are shown in Table 1. During the parental genotyping, M3 marker linked with $X a 7$ developed by Porter et al. 2003 was used. Phenotyping of the more advanced progeny, however already used the M5 marker because this was reported to be nearer to the $\mathrm{Xa} 7$ gene (Porter et al. 2003).

\section{Analysis of the Xa4-Linked MP Marker}

MP marker linked to the Xa4 gene developed by Ma et al. (1999) was used to detect the presence of the $X a 4$ in the B lines and R lines of Mestizo hybrids. One $\mu 1$ of 50-100 ng/ $\mu 1$ template DNA was dispensed in a $0.5 \mathrm{ml}$ PCR tube. Nineteen $\mu 1$ of a PCR cocktail (10x PCR buffer- $2 \mu 1,5 \mathrm{mM}$ dNTP$0.5 \mu 1,50 \mathrm{ng} / \mu 1 \mathrm{MP} 1$ primer- $2.0 \mu 1,50 \mathrm{ng} / \mu 1 \mathrm{MP} 2$ primer- $2 \mu 1$, Taq polymerase enzyme-1 $\mu$ l and sterile distilled water-11.5 $\mu 1$ ). The mixture was overlayed with one drop mineral oil loaded in the thermal cycler (MJ Research, Inc.) and run using the following profile: $94^{\circ} \mathrm{C}-5 \mathrm{~min}, 29 \mathrm{cycles}$ of $\left(94^{\circ} \mathrm{C}-30 \mathrm{sec}, 55^{\circ} \mathrm{C}\right.$ $30 \mathrm{sec}$, and $\left.72^{\circ} \mathrm{C}-1 \mathrm{~min}\right), 72^{\circ} \mathrm{C}-5 \mathrm{~min}$ and $4^{\circ} \mathrm{C}$-soaking.

The PCR products were run in agarose gel electrophoresis at 90 Volts. Amplified products in the gel was stained with Ethidium Bromide, viewed and 


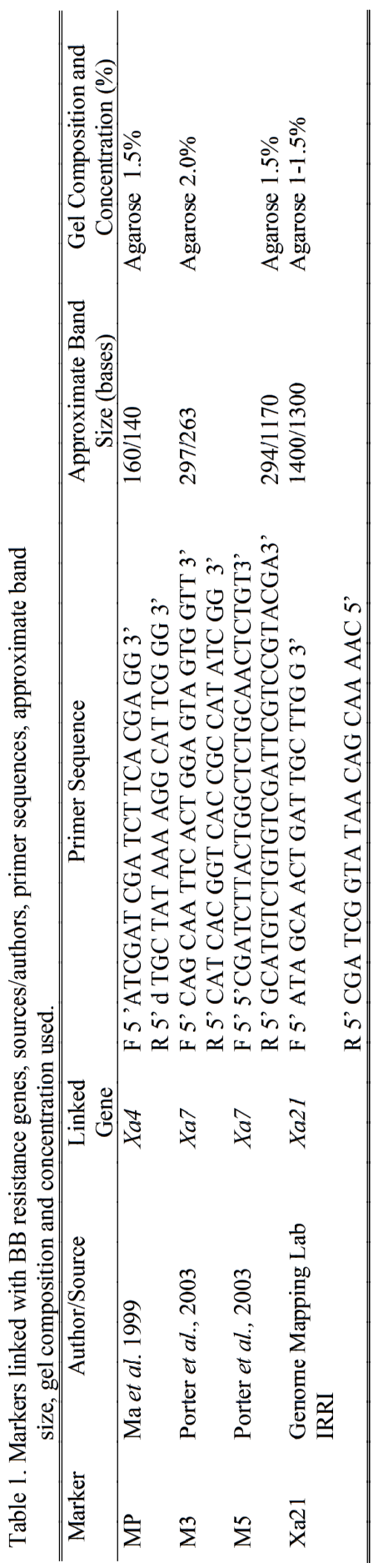


documented in a UV trans-illuminator attached to an Alpha Digi Doc Documentation System(Alpha Innotech).

Analysis of the Xa7-linked M3 marker

M3 Marker developed by Porter et al. (2003) was used in the parental genotyping to detect the presence of the $X a 7$ gene. One $\mu 1$ of 50-100 ng/ $\mu 1$ template DNA was dispensed in a $0.5 \mathrm{ml}$ PCR tube. Nineteen $\mu \mathrm{l}$ of a PCR cocktail (10x PCR buffer with $\mathrm{MgCl}_{2}-2 \mu 1,5 \mathrm{mM}$ dNTP-0.5 $\mu 1,50 \mathrm{ng} / \mu \mathrm{l}$ M3F primer-3.0 $\mu 1,50 \mathrm{ng} / \mu 1 \mathrm{M} 3 \mathrm{R}$ primer-3 $\mu 1$, Taq polymerase enzyme- $1 \mu \mathrm{l}$ and sterile distilled water-9.5 $\mu \mathrm{l}$ ). The mixture was overlayed with one drop mineral oil loaded in the PCR machine and run using the following profile: $94^{\circ} \mathrm{C}-4 \mathrm{~min}, 37$ cycles of $\left(94^{\circ} \mathrm{C}-1 \mathrm{~min}, 55^{\circ} \mathrm{C}-1 \mathrm{~min}\right.$, and $\left.72^{\circ} \mathrm{C}-2 \mathrm{~min}\right), 72^{\circ} \mathrm{C}-$ $8 \mathrm{~min}$ and $4^{\circ} \mathrm{C}$-soaking.

Gel electrophoresis and gel documentation was done as described earlier.

\section{Analysis of the Xa21-linked Xa21 marker}

Xa21 marker developed at the genome mapping lab at IRRI was used in detecting $X a 21$ gene in the $\mathrm{B}$ and $\mathrm{R}$ lines of Mestizo Hybrids. One $\mu 1$ of 50$100 \mathrm{ng} / \mathrm{ul}$ template DNA was dispensed in a $0.5 \mathrm{ml}$ PCR tube. Nineteen $\mu \mathrm{l}$ of a PCR cocktail (10x PCR buffer with MgCl2-2 $\mu 1,5 \mathrm{mM}$ dNTP- $0.5 \mu 1,50$ $\mathrm{ng} / \mu 1 \mathrm{Xa} 21 \mathrm{~F}$ primer- $1.0 \mu 1,50 \mathrm{ng} / \mu \mathrm{l}$ Xa21R primer- $1 \mu \mathrm{l}$, Taq polymerase enzyme-1 $\mu \mathrm{l}$ and sterile distilled water-13.5 $\mu \mathrm{l}$ ). The thermo-cycling profile, gel electrophoresis and gel documentation was the same as that of the Xa4 gene.

\section{Introgression of resistance genes to $B$ and $R$ lines}

The $\mathrm{B}$ and $\mathrm{R}$ lines of Mestizo hybrids 1, 2 and 3 were used as recurrent parents in backcross breeding (Figure 1). IRBB62 which contains a pyramid of $X a 4 / 7 / 21$ was used as the pollen donor for the production of the $\mathrm{F}_{1}$. Resistant $\mathrm{F}_{1}$ progeny were then used as gene donors for backcrossing to the recurrent $\mathrm{B}$ and $\mathrm{R}$ lines. Staggered planting of the recurrent parents (susceptible B and $\mathrm{R}$ lines) was done to ensure flowering synchronization with the resistant $F_{1}$. Continuous backcrosses to the recurrent $\mathrm{B}$ and $\mathrm{R}$ lines were done to introgress the target genes with phenotyping and genotyping for the target genes in each 


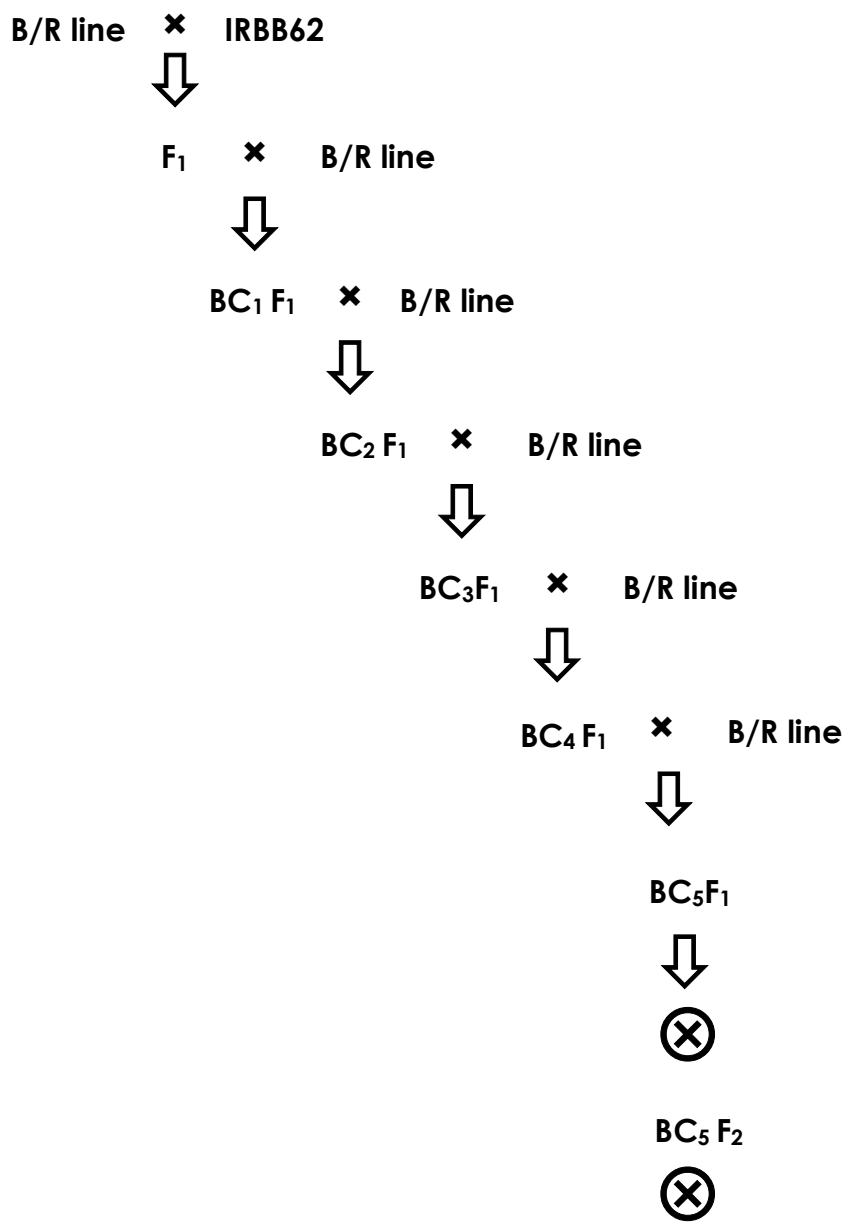

$\mathrm{BC}_{5} \mathrm{~F}_{3}$

Figure 1. Backcrossing scheme of introgression of $\mathrm{Xa}$ genes from IRBB62 to maintainer (B) and restorer (R) lines 
backcross generation.

The recurrent parents ( $\mathrm{B}$ and $\mathrm{R}$ lines) were always used as the female and were subjected to emasculation in the afternoon before the day of pollination. Pollinations were done in the morning at around 10:00 a.m. to 12:00 noon or until the dehiscence of anthers of pollen donors. Emasculated or pollinated spikelets in a panicle were covered with glassine bags to protect them from unwanted pollens (Figure 2a). The bagged panicles were checked regularly for the formation of $\mathrm{F}_{1}$ seeds (Figure $2 \mathrm{~b}$ ).

Selection of resistant progeny by phenotyping with diagnostic Xoo races and marker-aided selection.

For every backcross generation, the progeny of the different crosses were inoculated with diagnostic races for the target genes namely, (race1PXO61 to detect $\mathrm{Xa4}$, race2-PXO86 to detect $\mathrm{Xa} 7$ and race6-PXO99 to detect $X a 21)$. Resistant reaction of the progeny to each diagnostic race indicates the presence of the gene. The presence of the genes was further confirmed with linked markers. During the parental genotyping, M3 marker was used for $\mathrm{Xa}$, but later during the course of the study, a better marker (M5) (Porter et al. 2003) in terms of its closer proximity to the $\mathrm{Xa} 7$ gene became available so it was used in the marker analysis for $X a 7$ in different backcross progeny. The same $X a 21$ marker was used to detect $X a 21$ gene in the progeny.

\section{Analysis of the Xa7-linked M5 marker}

One $\mu \mathrm{l}$ of 50-100 ng/ul template DNA was dispensed in a $0.2 \mathrm{ml} \mathrm{PCR}$ tube. Nineteen $\mu 1$ of a PCR cocktail (10x PCR buffer $-2 \mu 1,5 \mathrm{mM}$ dNTP-0.5 $\mu 1,50 \mathrm{ng} / \mu 1 \mathrm{M} 5 \mathrm{~F}$ primer- $1.0 \mu 1,50 \mathrm{ng} / \mu 1 \mathrm{M} 5 \mathrm{R}$ primer- $1 \mu 1$, Taq polymerase enzyme- $1 \mu 1$ and sterile distilled water-13.5 $\mu \mathrm{l}$ ). The thermocycling profile, gel electrophoresis and gel documentation was the same as that of the M3 marker of Porter et al. (2003).

Agronomic data such as plant height, number of days to $50 \%$ flowering and number of days to maturity were gathered from the parents and for each backcross generation to be able to compare whether the advanced lines had already attained the phenotype of the original $\mathrm{B}$ and $\mathrm{R}$ lines. 


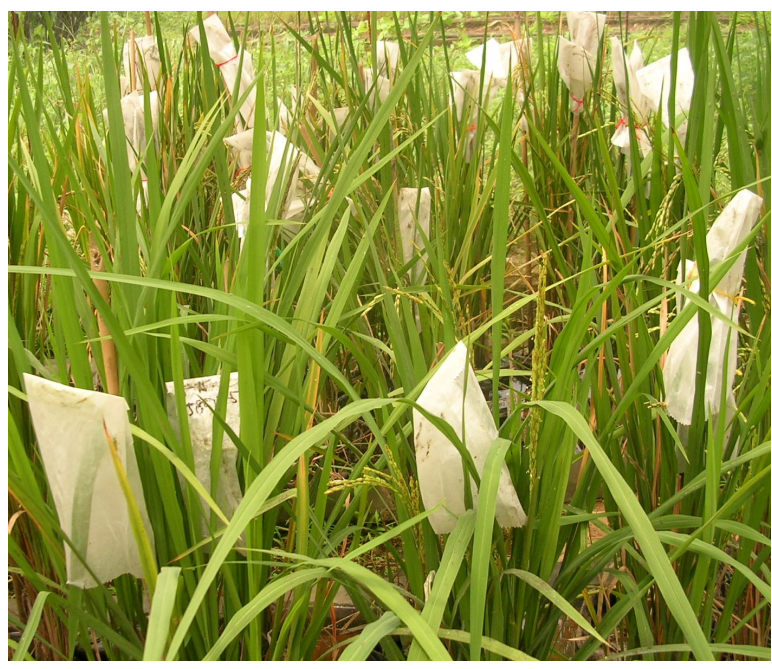

a

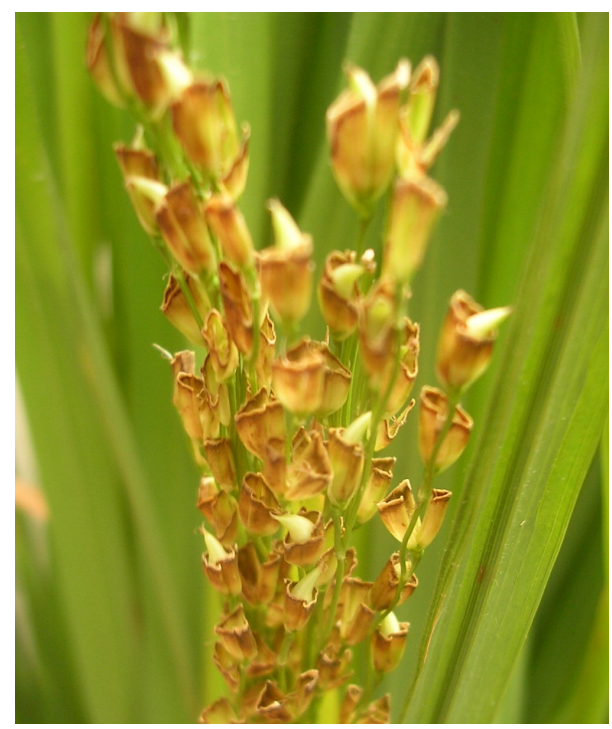

b

Figure 2. a) Bagged pollinated panicles, b) $F_{1}$ seeds formed 


\section{RESULTS AND DISCUSSION}

Reaction of Mestizo hybrids, maintainers and restorers to PXO races

Results of the phenotyping experiment of the three Mestizo hybrids and their B and R lines (Table 2) revealed that Mestizo 1 and its maintainer line IR58025B were moderately susceptible (MS) or susceptible (S) to most of the Xoo races ( 7 out of 12 isolates for Mestizo 1, and 11 out of 12 isolates for IR58025B). The R line of Mestizo 1 (IR34686-179-1-2-1R) however, showed resistance/moderate resistance to 7 out of 12 isolates. Mestizo 2, its $B$ and $R$ lines (IR68888B and IR62161-184-3-1-3-2R) as well as Mestizo 3 , its B and R lines (IR68897B and IR60819-34-2R) showed resistance (R) or moderate resistance (MR) to approximately half of the isolates. The Mestizo hybrids, their B and R line (except IR58025B, the B line of Mestizo 1) therefore generally possess resistance to approximately half of the Xoo races. This explains the earlier field observations on the intermediate reaction of the Mestizos to BB (De Leon et al. 2003). Mestizo 1 however is susceptible to more races and is more susceptible than Mestizos 2 and 3.

When the reaction pattern of the Mestizo hybrids and their $\mathrm{B}$ and $\mathrm{R}$ lines were compared with that of Carillo et al. 2004, it was observed that all the Mestizos and their B and R lines (except IR58025B,) showed a reaction pattern similar to IRRB4, the NIL containing $X a 4$, suggesting the presence of $\mathrm{Xa} 4$ in these lines. Even if the $\mathrm{Xa} 4$ gene is lacking in 1R58025B, the B line of Mestizo 1, IR34686R, the R line of Mestizo 1 possessed the gene that is why Mestizo 1 showed a typical reaction pattern of a line possessing the $\mathrm{Xa} 4$ gene.

All the hybrids as well as their maintainer and restorer lines were susceptible to PXO86 and PXO99, the diagnostic races of $\mathrm{Xa} 7$ and $\mathrm{Xa21}$, suggesting the absence of $X a 7$ and $X a 21$ genes in these lines.

\section{Resistance gene genotyping of $B$ and $R$ lines}

All the B and R lines of Mestizo hybrids except IR58025B (B line of Mestizo 1) showed the $\sim 160 \mathrm{bp}$ resistance allele linked with the $\mathrm{Xa} 4$ gene 


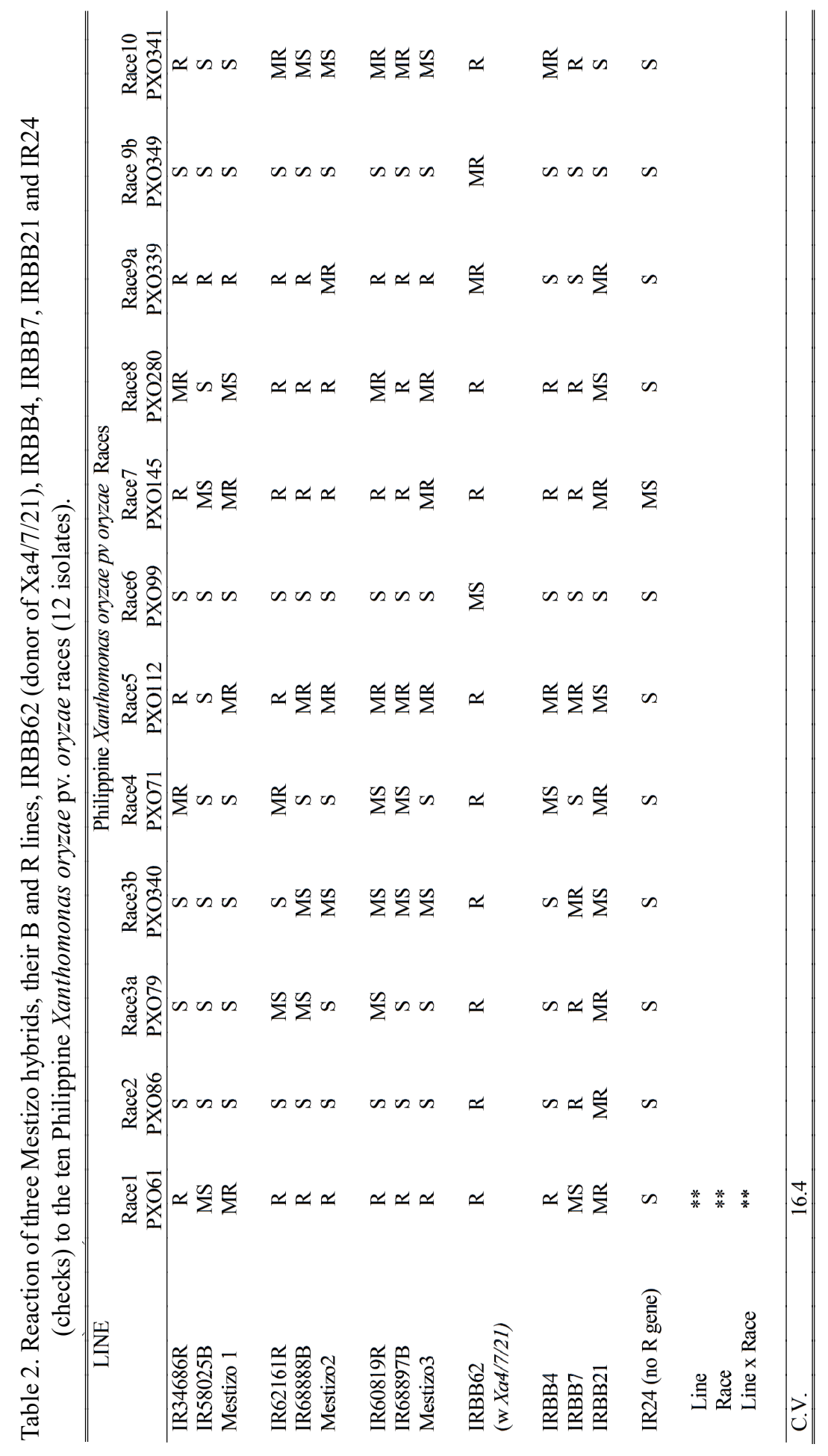


(Figure 3a). This data together with the phenotypic results (Table 2) confirmed that all the B and R lines of three Mestizo hybrids, except IR58025B contain the $\mathrm{Xa} 4$ gene for resistance to $\mathrm{BB}$. This explains their resistant to moderately resistant reaction to race 1-PXO61.

Figure $3 \mathrm{~b}$ shows the results of DNA marker analysis using the $\mathrm{M} 3$ marker linked with $\mathrm{BB}$ resistance gene $\mathrm{Xa}$ 7. All the $\mathrm{B}$ and $\mathrm{R}$ lines of Mestizo hybrids did not show the $\sim 297 \mathrm{bp}$ size (upper) band linked with the resistance gene $X a 7$. Only IRBB7, the NIL containing $X a 7$ and the IRBB61 donor that also contained $X a 7$ showed this allele. These data together with the susceptible reaction of the lines to the diagnostic race for $\mathrm{Xa} 7$ (race2-PXO86, Table 2) confirmed that all the $\mathrm{B}$ and $\mathrm{R}$ lines of Mestizo hybrids do not contain the $\mathrm{Xa} 7$ gene.

The $\mathrm{B}$ and $\mathrm{R}$ lines of Mestizo hybrids also lacked the $\mathrm{Xa21}$ gene for resistance to $\mathrm{BB}$. This was proven through the absence of the $\sim 1.4 \mathrm{~Kb}$ (upper) band linked with the Xa21 gene in these lines (Figure 3c). Together with the susceptible phenotypic reaction to race6-PXO99, the diagnostic race for Xa21 (Table 2), this genotypic data confirms the absence of Xa21 in the B and R lines of Mestizo hybrids.

\section{Introgression of resistance genes to $B$ and $R$ lines}

Bacterial blight resistance genes alone or in combination were introgressed into the $\mathrm{B}$ and $\mathrm{R}$ lines Mestizo hybrids. Based on the reaction to diagnostic $X o o$ races, $X a 4 / 7 / 21, X a 4 / 21$ and $X a 4 / 7$ were incorporated to $\mathrm{BC}_{5} \mathrm{~F}_{2}$ progeny (or $\mathrm{BC}_{5} \mathrm{~F}_{3}$ seeds) of IR34686R, IR60819R, IR62161R, IR68888B, and $\mathrm{BC}_{4} \mathrm{~F}_{1}$ progeny $\left(\mathrm{BC}_{5} \mathrm{~F}_{2}\right.$ seeds) of IR58025B and IR68897B (Table 3). The generation of the latter two lines was behind due to a synchronization problem and the attack of molds on the $F_{1}$ seeds earlier.

The presence of the resistance genes was confirmed with the analysis of the linked DNA markers. For the marker analysis of the different backcross progeny, a better marker for $\mathrm{Xa} 7$ was used instead of the M3 marker by Porter et. al. (2003). Figure 4 shows the presence of $\sim 294$ bp (lower) band linked with $X a 7$ resistance gene in the IRBB62 donor and IR34686R/IRBB61 progeny. Unlike the M3 marker linked with $X a 7$ that was used in the parental genotyping, the resistance allele in the M5 marker was the lower band. The 


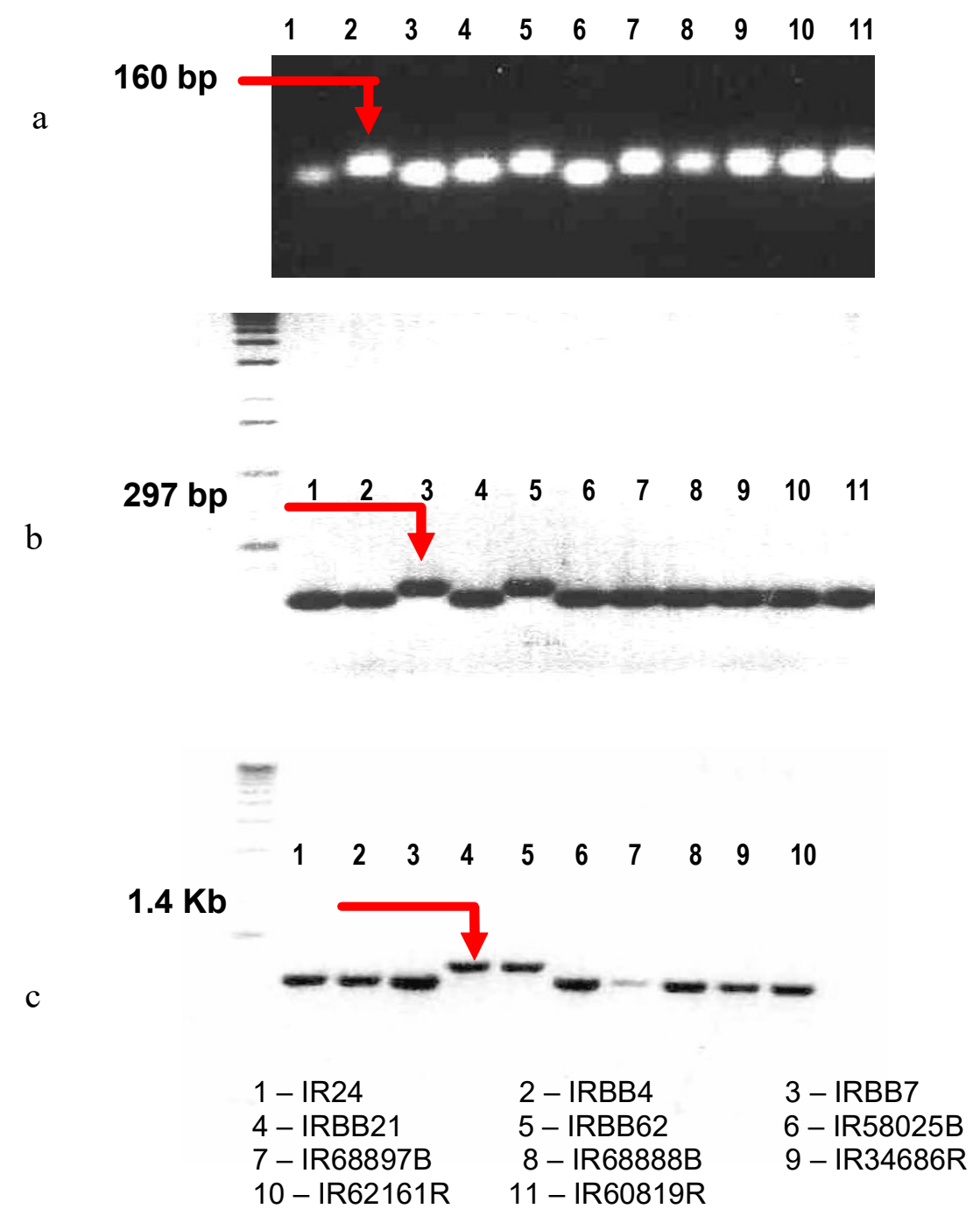

Figure 3. Banding patterns of Mestizo hybrid $\mathrm{B}$ and $\mathrm{R}$ lines a) MP marker linked with Xa4 showing Lanes 2, 5, 7-11 which correspond to IRBB4, IRBB62 (donor), IR68897B, IR68888B, IR34686R, IR62161R and IR60819R showed the $160 \mathrm{bp}$ upper band linked with resistance gene Xa4. b). M3 marker linked with $\mathrm{Xa} 7$ showing only lanes 3 (IRBB7) and 5 (IRBB62, donor) have the 297 bp (upper) band linked to the $X a 7$ resistance gene. c) Xa21 marker linked with Xa21 resistance gene showing only lanes 4 (IRBB21) and 5 (IRBB62, donor) have the $1.4 \mathrm{~kb}$ upper) band linked with Xa21 resistance gene. 
susceptible IR34686B showed the $\sim 1,170$ bp band which is linked with susceptibility. This confirms the introgression of the $\mathrm{Xa} 7$ gene in the advanced backcross progeny. The presence of the $1.4 \mathrm{~Kb}$ band linked with $\mathrm{Xa} 21$ resistance gene were also confirmed in the advanced backcross progeny.

Only M5 marker to detect presence of $\mathrm{Xa} 7$ gene and $\mathrm{Xa} 21$ marker to detect presence of $X a 21$ genes were used in the genotyping of the advanced lines since based on earlier analysis, MP marker was not very reliable in detecting presence of $\mathrm{Xa} 4$ gene in the progeny. This was also observed by Borines (2001). When this marker was tested to the progeny, no co-segregation with the phenotype was observed, implying that the marker may not be that close to the $\mathrm{Xa} 4$ gene. Selection of $\mathrm{Xa} 4$ in the progeny was therefore based on the resistant reaction to the diagnostic race1-PXO61.

Table 3 also shows how many progeny with a particular resistance gene were produced in the advanced lines, the mean lesion length and their reaction to three diagnostic races. The plants that showed produced very short lesions upon inoculation with three diagnostic races, PXO61, PXO86 and PXO99 also contained the three genes $(\mathrm{Xa} 4 / 7 / 21)$ which were confirmed through DNA marker analysis. Those which possessed only a single resistance gene showed resistance only to its corresponding diagnostic race (i.e. those which possessed only $\mathrm{Xa} 4$ was resistant only to race 1-PXO 61), while those which possessed $\mathrm{Xa} 4 \mathrm{IXa} 7$ showed short resistance to both race1-PXO 61 and race2-PXO 86 susceptibility to race6-PXO 99). The lines containing Xa4/21 showed resistance to PXO61 and PXO99.

The lines possessing two or three genes conferred a higher level of resistance (shorter lesions) to the diagnostic races of $X$. oryzae pv oryzae that were used to select them and they showed a wider resistance spectrum (i.e., resistance to more races). Agronomic data such as plant height, number of days to $50 \%$ flowering and number of days to maturity in the advanced almost nearly resemble that of the recurrent $B$ and $R$ lines.

It was proven in this research that all of the $B$ and $R$ lines of Mestizo hybrids except IR58025B, the B line of Mestizol already contained the Xa4 gene. The presence of the gene in these lines explains the intermediate reaction of the Mestizo hybrids to BB in field observations. This was most probable because lines containing $\mathrm{Xa} 4$ has been extensively used in breeding new rice varieties earlier. It was reported by Mew et al. (1992) that most of the improved rice cultivars planted on about $90 \%$ of the rice land in the Philippines 


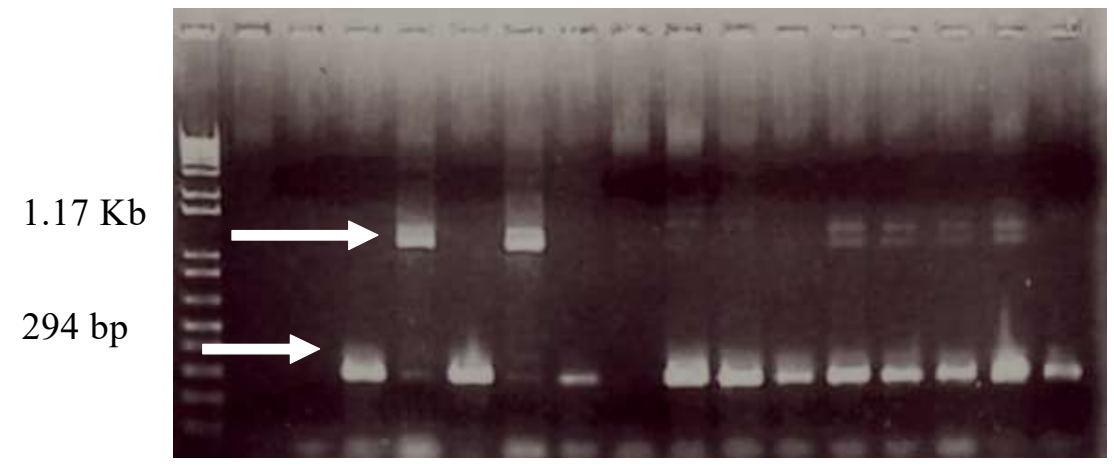

$1.17 \mathrm{~Kb}$

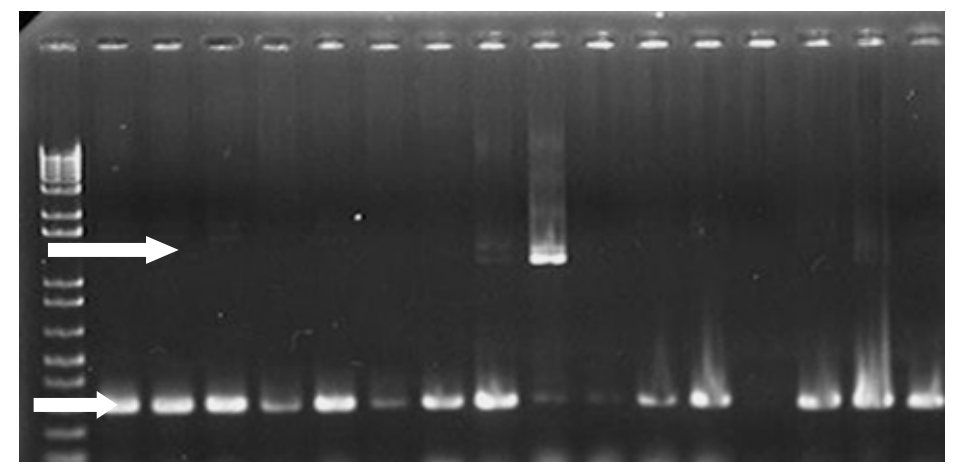

Figure 4. Band patterns of IR34686R advanced backcross progeny showing the expected 294 bp band (lower band) linked with $X a 7$ resistance gene. Few progeny showed the $1.17 \mathrm{~kb}$ band (upper band) linked with susceptibility. 


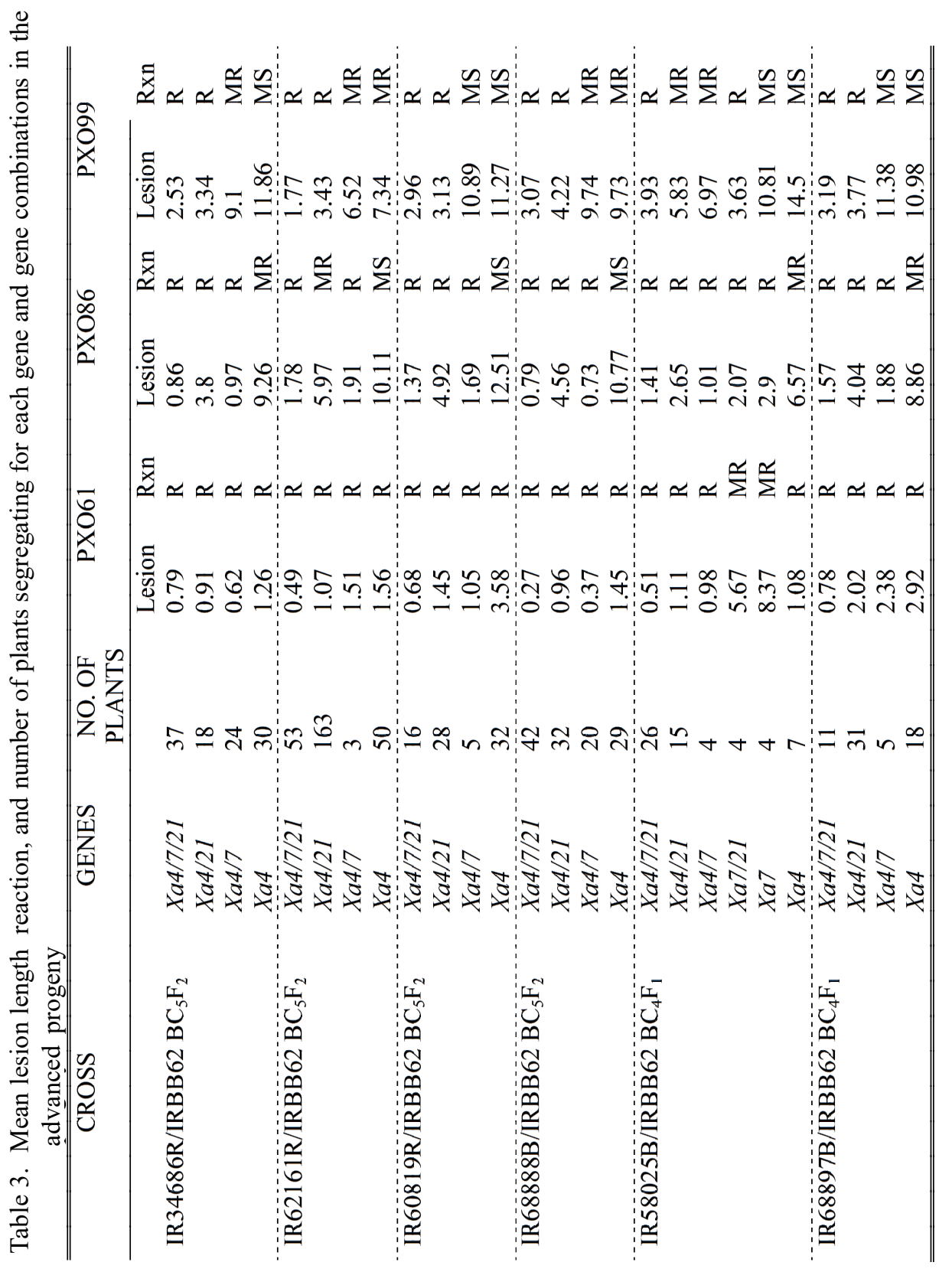


have possessed the $\mathrm{Xa} 4$ resistance gene. Furthermore it was reported by Leach et al. (2001) that Xa4 was incorporated into the commercial varieties by IRRI in the early 1970 's and was extensively deployed in the Philippines. It is most probable that the lineage of the $\mathrm{B}$ and $\mathrm{R}$ lines of Mestizo hybrids were among those lines where $\mathrm{Xa} 4 \mathrm{had}$ been incorporated by earlier breeders.

Even though $\mathrm{Xa} 4$ is already present in most of the $\mathrm{B}$ and $\mathrm{R}$ lines of Mestizo hybrids and also in the Mestizo hybrids, this resistance gene has started to be overcome by newly emerging Xoo races. After cultivars with $\mathrm{Xa} 4$ gene were introduced in the 1970's, race 1 of Xoo (which Xa4 shows resistance to) declined but races 2 and 3 appeared which are virulent to lines containing Xa4 (Mew et al. 1992). The incorporation of another resistance gene into the hybrids and their parental materials is necessary to attain durable resistance to bacterial blight. The presence of more than one gene (gene pyramids) is much better so that resistance will not be easily overcome by the pathogen races.

One of the target resistance genes introgressed into the $\mathrm{B}$ and $\mathrm{R}$ lines was $\mathrm{Xa} 7$ which shows resistance to races2-PXO86, race 3-PXO79, race 5PXO112, race7-PXO145 and race8-PXO280 (Carillo et al. 2003). This gene was predicted to be a durable resistance gene because the gene was shown to cause mutation to the Xoo pathogen attacking it (Vera Cruz et.al., 2000). On the other hand, Xa21 gene from Oryza longistaminata conferred broad-spectrum resistance to most $X$. oryzae pv oryzae races (Carillo et al. 2003, Zhang et al. 1998, Borines, 2001). With the incorporation of Xa7 and $X a 21$, together with $X a 4$ in the B and R lines of Mestizo hybrids, the level of resistance of the hybrids that will be produced from them will be further enhanced. The resistance of the hybrids to $\mathrm{BB}$ will be more durable, long lasting and solve the problem of bacterial blight so that maximum heterosis for yield can be obtained from them.

\section{CONCLUSION AND RECOMMENDATION}

Mestizo hybrids 1, 2 and 3, their maintainer and restorer lines except IR5805B showed resistance to approximately half of the 12 Xoo isolates representing 10 races which was observed to be due to the $\mathrm{Xa} 4$ gene they possess. The lines, however, did not contain $\mathrm{Xa}$, a gene with reported durable resistance to $\mathrm{BB}$ and $\mathrm{Xa} 21$ which posses a broad spectrum resistance

to BB. $\mathrm{Xa} 4 \mathrm{Xa} 7$ and $\mathrm{Xa21}$ were introgressed alone or in combination to 
$\mathrm{BC}_{5} \mathrm{~F}_{2}$ progeny (or $\mathrm{BC}_{5} \mathrm{~F}_{3}$ seeds) of $\mathrm{R}$ line IR34686R IR60819R IR62161R and IR68888B. Resistance genes were also incorporated to $\mathrm{BC}_{4} \mathrm{~F}_{1}$ progeny (or $\mathrm{BC}_{4} \mathrm{~F}_{2}$ seeds) of IR58025B and IR68897B.

The presence of the target genes in the advanced backcross progeny were confirmed through their reaction to the diagnostic Xoo races and DNA markers linked with the genes. These lines containing gene pyramids had increased resistance to bacterial blight and a wider resistance spectrum to $X o o$ races. The advanced lines can be used as the resistance gene sources for the improvement of the BB resistance of the Mestizo hybrids to solve the pressing problem of $\mathrm{BB}$ disease. The seeds of the advanced lines were forwarded advanced at PhilRice and currently used to produce bacterial blight resistant Mestizo hybrids and some other hybrids that are now in the pipeline.

\section{ACKNOWLEDGMENT}

The senior author wishes to acknowledge PhilRice for the financial support to this project and to IRRI for the support extended in terms of the chemicals used for MAS, for the BB NILs and Xoo isolates and to the two institutions for allowing us to conduct portions of this research in their laboratory and greenhouse, respectively.

\section{LITERATURE CITED}

BLAIR, M.W. and S.R. MC COUCH. 1997. Microsatellite and sequence tagged site markers diagnostic for the rice bacterial leaf blight resistance gene $X a-5$. Theor.Appl.Genet.95:174-184.

BORINES, L.M. 2001. Marker-aided Pyramiding of Bacterial Blight Resistance Genes in Maintainer Lines of Rice (Oryza sativa L.) Hybrids. Ph.D. Dissertation, UPLB College, Laguna. 133 pp.

CARILLO, G. I. OÑA, P. VIRK, and C. VERA CRUZ. 2003. Phenotype and molecular characterization of BB resistance of improved modern varieties, IRRI elite lines and new plant types of rice. Poster presented during the 34th annual scientific meeting of the Pest Management Council of the Philippines. May 6-9, 2003, Cebu Business Hotel, Cebu City.

CHEN, S., X.H. LIN, C.G. XU and Q. ZHANG. 2000. Improvement of bacterial blight resistance of "Minghui 63", an elite restorer line of hybrid rice by molecular marker-assisted selection. Crop Sci. 40:239-244. 
CHEN, S., X.H. LIN, C.G. XU and Q. ZHANG. 2001. Improving bacterial blight resistance of ' 6078 ', an elite restorer line of hybrid rice, by molecular marker-assisted selection. Plant Breeding. 120: 133- 137.

DE LEON, J.C. 2003. Development of hybrid rice technology in the Philippines. pp 1-14 In: Hybrid Rice Seed Production Training Manual. PhilRice Maligaya, Muñoz, Nueva Ecija. 174 pp.

DE LEON, J.C., E.D. REDOÑA and M.G. GASPAR, 2003. The PhilRice hybrid rice R \& D. program. pp. 22. In: Hybrid Rice Seed Production Training Manual. PhilRice Maligaya, Muñoz, Nueva Ecija. 174 pp.

HUANG, N., E.R. ANGELES, J. DOMINGO, G. MAGPANTAY, S. SINGH, G. ZHANG, N. KUMARAVADIVEL, J. BENNET and G.S. KHUSH. 1997. Pyramiding of bacterial blight resistance genes in rice: Marker assisted selection using RFLP and PCR. Theor. Appl. Genet. 95:313-320.

KAUFMAN, H.E., A.P.K. REDDY, S.P.Y.HSIEH and S.D. MERCA. 1973. An improved technique for evaluating resistance of rice varieties to Xanthomonas oryzae. Plant Dis Rep 57:537-541.

KINOSHITA,T. 1995. Report of committee on gene symbolization, nomenclature and linkage groups. Rice Genet.Newslet. 12:9-153.

LEACH, J.E., C. M. VERACRUZ, J. BAI and H. LEUNG. 2001. Pathogen fitness penalty as a predictor of durability of disease resistance genes. Ann. Rev. Phytopathology 39: $187-224$.

MA, B.J., W.M. WANG, B. ZHAO, Y.L. ZHOU, L.H.ZHU, and W.X. ZHAI. 1999. Studies of PCR marker for the rice bacterial blight resistance gene Xa4. Hereditas (Beijing). 21(3):711-714.

MADAMBA, M.R.S.B. 2000. Molecular and phenotypic characterization of Xanthomonas oryzae pv. oryzae Ishiyama Dye Swings et al. adapted on Xa21 gene for rice bacterial blight resistance. Unpublished MS. Thesis. University of the Philippines, Los Baños, College, Laguna. 74 pp.

MEW, T.W., C.M. VERACRUZ and E.S. MEDALLA. 1992. Changes in race frequency of Xanthomonas oryae pv. oryzae in response to the planting of rice cultivars in the Philippines. Plant Dis. 76:1029-1032.

OGAWA, T., R. E. TABIEN, T. YAMAMOTO, G.A. BUSTO and R. IKEDA. 1990. Breeding for near-isogenic lines resistant to bacterial blight in rice. Rice Genet. Newsl. 7:10.

OGAWA, T., T. YAMAMOTO, G.S. KHUSH and T.W. MEW. 1991. Breeding near-isogenic lines of rice with single genes for resistance to bacterial blight pathogen (Xanthomonas campestris pv oryzae). Japan J. Breed. 41:523-529. 
PORTER, B.W., J.M. CHITOOR, Y.M. SASAKI and F.F. WHITE. 2003. Development and mapping of markers linked to the rice bacterial blight resistance gene Xa7. Crop Sci. 43:1-9.

REDOÑA, E.D., MALABANAN, F.M., JAVIER, L.J., YABES, S.A., ORDOÑEZ, S.A. and S. R. OBIEN. 2001. Exploiting rice heterosis in the Philippines. pp. 193-203. In: Rice Research for Food Security and Poverty Alleviation. Pend, S. and Hardy, B. eds. IRRI. 692 pp.

RONALD, P.C., ALBANO, R. TABIEN, L. ABENES, K. WU, S. MC COUCH and S.D. TANKSLEY. 1992. Genetic and physical analysis of the rice bacterial blight resistance locus, Xa21. mol. Gen.Genet. 236:113-120.

SANCHEZ, A.C., D.S. BRAR, N. HUANG, Z. LI and G.S. KHUSH. 2000. Sequence tagged site marker-assisted selection for three bacterial blight resistance genes in rice. Crop Sci. 40:792-797.

SEBASTIAN, L.S. 2004. Foreword. I: Hybrid Rice Seed Production Training Manual. Mina-Miguel S.S. (eds.) Philippine Rice Research Institute, Maligaya, Muñoz, Nueva Ecija. 174 pp.

VERACRUZ, C.M., J. BAI, I. ONA, H. LEUNG, R.J. NELSON, T.W. MEW and J.E. LEACH. 2000. Predicting durability of disease resistance gene based on an assessment of the fitness loss and epidemiological consequences of avirulence gene mutation. PNAS. 97:13500-13505.

VIRMANI, S.S. 2001. Opportunities and challenges of developing and using hybrid rice technology in the tropics. pp 151-166. In: Rice Research for Food Security and Poverty Alleviation. Pend, S. and Hardy, B. eds. IRRI. 692 pp.

XU, W., E.D. REDOÑA, H.I. DE LACRUZ, and S.R. OBIEN. 1995. Cytoplasmic malesterile and restores lines for hybrid rice breeding. Philipp J Crop Sci 20:29-37.

YOSHIMURA, S., A. YOSHIMURAA, N. IWATA, S.R. MCCOUCH, M.L.ABENES, M.R. BARAOIDAN, T.W.MEW and R. NELSON. 1995. Tagging and combining bacterial blight resistance genes in rice using RAPD and RFLP markers. Mol. Breeding 1: 375-387.

ZHANG, Q., S.C. LIN, B.Y.ZHAO, C.L. WANG, W.C. YANG, Y.L. ZHOU, D.Y. LI, C.B. CHEN and L.H. ZHU. 1998. Identification and tagging a new gene for resistance to bacterial blight (Xanthomonas oryzae pv. oryzae) from O. rufipogon. Rice Genet. Newlett. 15:138-142. 